\title{
A Comparative Study on the Vocabulary Learning of Children According to Selective Attention Latent Group
}

\author{
Dongsun Yim, Jiyun Han, Eun Song, Sookyung Lee, Jia Han \\ Department of Communication Disorders, Ewha Womans University, Seoul, Korea
}

Correspondence: Dongsun Yim, PhD Department of Communication Disorders, Ewha Womans University, 52, Ewhayeodae-gil, Seodamun-gu, Seoul 03760, Korea

Tel: $+82-2-3277-4332$

Fax: +82-2-3277-2122

E-mail: sunyim@ewha.ac.kr

Received: October 5, 2019

Revised: November 8, 2019

Accepted: November 25, 2019

This work was supported by the Ministry of Education of the Republic of Korea and the National Research (No. NRF-2019R1A2C1007488).
Objectives: The purpose of this study was to examine whether selective attention is significantly influential in vocabulary learning, by dividing preschoolers with specific language impairment (SLI) and those with typical development (TD) into clusters according to selective attention, and by comparing the groups'vocabulary learning ability. Methods: 16 children with SLI and 15 children with TD participated in this study. Variable clustering with selective attention as a latent variable was employed to separate the children into two groups. Children in both groups had book-reading intervention 12 times, followed by measurement of the amount of target words in receptive and expressive types. Results: All three categories of receptive language, receptive vocabulary, and selective attention were statistically significant factors in cluster variables. All children divided two groups according to receptive language, receptive vocabulary, and selective attention showed a significant difference in their mean age, whereas their difference in nonverbal intelligence had no significance. With age and nonverbal IQ controlled, the amount of receptive vocabulary was significantly different in two groups. Conclusion: The results highlight that selective attention along with existing language ability plays an important role in vocabulary learning, which may lead to difference between individuals in vocabulary learning ability. Our findings suggest that children's receptive vocabulary learning may depend on their selective attention.

Keywords: vocabulary learning, latent variable, selective attention, cluster analysis, individual differences, inhibition
단순언어장애(SLI) 아동은 발달상의 뚜렷한 동반 장애가 없으나 수용, 표현 어휘 및 언어능력이 또래와 비교하여 낮은 아동을 말한 다(Leonard, 1986). 아동의 초기 발달 과정에서 아동의 운동기능, 언어습득 및 인지기능이 상호의존적으로 나타난다는 선행 연구에 서도 단순언어장애 아동은 언어뿐만 아니라 정보 처리 능력에 한계 가 있다는 논란과 함께 처리 속도나(Kail, 1994) 처리 용량(Kail \& Salthouse, 1994; Montgomery, 1993)의 제한에 대한 문제가 제기된 바 있으며, 최근 연구에서는 아동의 언어발달에 있어서 집행기능의 중요성이 부각되면서 단순언어장애 아동이 집행기능에서 제한이 있음을 많은 연구들이 제시하고 있다(Chun \& Yim, 2017; Roello, Ferretti, Colonnello, \& Levi, 2015; Yang \& Yim, 2018; Yoo \& Yim, 2018). 집행기능(executive function)은 인간의 사고, 행동, 주의집중 조 절에 관여하는 인지적 과정으로(Zelazo \& Müller, 2010) 이와 같은 인지능력에는 주의의 집중과 유지, 정보의 작업기억(working memory)내 보유와 조작, 방해자극 억제(inhibition), 과제 및 자극 간 주의집중 전환(switching), 문제해결 등이 포함된다(Kapa, Plante, \& Doubleday, 2017). 아동은 일상생활에서 사회적, 정서적, 정신 적인 다양한 문제를 해결하기 위해 자신의 충동 및 저항을 조절하 거나 유연하게 전환하면서 자신의 정보를 조작하고 활성화시킬 수 있어야 한다(Miller, Kail, Leonard, \& Tomblin, 2001). 이러한 집행 기능은 유아기에 발현되어 청소년기에 이르기까지 점차 발전하며, 주로 4-5세에 발달한다고 알려져 있다(Marcovitch \& Zelazo, 2009). 
Garon, Bryson과 Smith (2008)가 제안한 집행기능 하위 요소 발 달 위계에 따르면 주의집중은 모든 집행기능의 기저에 있는 것으로 비교적 이른 시기에 발달한다. 인간의 감각 체계는 주변의 모든 정 보를 처리할 수 없으므로, 정보의 관련성을 변별하여 관련 있는 정 보에만 주의를 집중하고 관련 없는 정보는 억제함으로써 정보를 처 리하는 주의집중 조절 기제가 기능하게 된다(Spaulding, 2010). 이 러한 억제 및 주의집중 조절 메커니즘은 그 세부적 측면을 학자들 마다 서로 다른 기준으로 분류하여 개념화하기 때문에 보편적으로 정의되지 않고 있으나, 선택적 주의집중력은 관련 없는 정보를 무시 하고 목표 자극에 집중하는 기능을 하므로 억제 능력의 범주에 해 당한다고 볼 수 있다. 이러한 억제 능력은 정보를 처리하는 과정에 서 불필요한 정보를 선별하여 무시하는 과정을 통해 문제를 효율 적으로 해결할 수 있도록 한다. 즉, 선택적 주의집중력을 효율적으 로 사용하는 것은 문제를 해결하는 데 필요한 처리 공간을 줄어들 게 하는 적극적인 과정이다(Wilson \& Kipp, 1998).

이러한 선택적 주의집중력은 말 변별, 언어적 기능, 비문자적 언 어 등 다양한 언어발달에 영향을 미치며 특히 어휘 학습에 중요한 요인으로 주목받고 있다(Spaulding, 2010; Yoon \& Yim, 2019). 선택 적 주의집중력은 아동이 주변 환경에서 필요 없는 정보는 억제하고 필요한 정보는 선택하여 목표 어휘에 집중할 수 있게 하는데, 이는 학습에 개인차를 야기할 수 있다(Roello et al., 2015). 즉, 목표단어 와 무관한 자극의 간섭에 대하여 억제 기능이 적절하게 작동한다면 작업기억 내에 부호화 되어 있지만 목표단어와는 무관한 정보를 능동적으로 저지할 수 있으므로, 억제능력은 언어처리 및 어휘 학 습에 중요한 기능을 한다고 할 수 있다(Wilson \& Kipp, 1998).

단순언어장애 아동과 일반 아동의 선택적 주의집중력에 대한 선 행연구를 살펴보면, 단순언어장애 아동과 일반 아동의 억제기능을 구어와 비구어 측면에서 평가하여 비교한 Bishop과 Norbury (2005) 는 언어기능과 억제과제 수행 간 정적상관이 나타난 점을 들어 억 제능력이 언어학습에 유의미함을 확인한 바 있다. 학령전기 단순언 어장애 아동과 일반 아동을 대상으로 문제표현, 억제능력, 문제계 획과 관련한 집행기능 과제를 실시한 결과, 단순언어장애 아동 그 룹은 모든 과제에서 일반 아동에 비해 낮은 수행능력을 나타냈으 며, 학령기 아동을 대상으로 한 연구에서도 단순언어장애 아동 집 단이 작업기억, 집중력, 억제, 작업기억과 같은 집행기능에 결함이 있는 것으로 나타났다(Ebert \& Kohnert, 2011; Montgomery, Evans, \& Gillam, 2009). 또한 학령기 자폐범주성장애 아동, 정상발달 아동, 단순언어장애 아동을 대상으로 선택적 주의집중력에 어떠한 차이가 있는지 살펴본 Roebuck, Sindberg와 Ellis Weismer (2018) 도 자폐범주성장애 아동과 단순언어장애 아동 집단 모두 정상발달
아동 집단에 비해 선택적 주의집중력 과제에서 수행능력이 떨어지 는 것으로 나타났으며, 장애가 아닌 언어능력으로 27 명의 언어발달 지연 집단과 33 명의 언어발달이 정상 범주인 집단으로 구분하였을 때 청각적 억제 과제에서 장애 유무와 관계없이 언어발달이 느린 집 단의 수행능력이 더 떨어지는 것으로 나타났다. 이와 같은 연구결 과는 아동의 언어발달과 선택적 주의집중력이 밀접하게 관련됨을 시사한다. 국내에서는 주로 어휘발달지연 아동의 선택적 주의집중 력 및 억제에 대한 연구들이 이루어졌으며, 학령기 단순언어장애 아동의 어휘 학습 예측요인에 관해 의미점화와 더불어 간섭 효과 를 살펴본 Yang, Yim과 Bae (2015)에 의하면 아동이 다양한 자극 중에서 어휘습득과 관련 없는 자극을 배제하면서 어휘집을 구성하 는데 이 과정에서 목표단어에 필요한 단서를 알아채지 못하거나 목 표단어와 무관한 자극을 식별하지 못하면 비효율적 어휘 학습이 초래된다. 즉, 언어 자극을 지각하는 데 있어서 관련 없는 정보의 간 섭을 억제하는 능력이 어휘능력에 유의한 영향을 줄 수 있다고 가 정하여 연구한 결과, 일반 아동 집단의 어휘 학습능력을 예측하는 요인은 간섭 과제 반응속도로 나타난 반면, 단순언어장애 아동 집 단에서는 의미점화 과제에서의 반응속도가 어휘 학습 예측요인으 로 확인되었다. 이는 Wilson과 Kipp (1998)의 '비효율적 억제 가설 (inefficient inhibition hypothesis)'과 같은 맥락으로, 능동적인 억 제 능력이 어휘를 효율적으로 학습하는 데 도움을 준다는 점을 의 미한다. 목표단어와 관련 없는 간섭자극을 억제하는 것은 목표단 어에 대한 단서가 되는 점화자극을 받아들이는 것보다 적극성이 더 요구되며, 더 강력하게 작용한다. 이러한 억제 능력이 단순언어 장애 아동 집단에 비해 일반 아동 집단에서 어휘 학습능력을 보다 잘 설명할 수 있는 것으로 나타난 것은 효율적인 어휘 학습을 위해 억제 능력이 필요하며, 단순언어장애 아동도 이러한 억제 능력을 향상시키는 것이 어휘 학습에 도움이 될 수 있다는 점을 시사한다.

앞서 언급한 바와같이 어휘 학습능력은 아동언어발달의 중요한 지표가 될 수 있다. 아동의 어휘 학습은 장기기억에 저장되어 있는 지식을 활용할 때 더욱 촉진되기 때문에(Gathercole, Willis, Emslie, \& Baddeley, 1992) 선택적 주의집중력과 동시에 아동이 보유한 기존 언어능력 또한 어휘 학습에 중요한 변인이라고 할수 있다.

본 연구에서는 전통적으로 어휘능력에 따라 집단을 나누는 것 이 아니라, 어휘 학습에 중요한 요소로 밝혀진 선택적 주의집중력 과 어휘능력의 잠재변인에 따라 아동들을 군집화하고 그 잠재변인 에 따라 집단을 나누어 아동의 어휘 학습 능력에 어떠한 차이가 있 는지 알아보고자 하였다. 이러한 집단구분 변인에 언어능력과 함께 정보처리에 필수적인 선택적 주의집중력을 포함한다면 아동 개개 인의 어휘 학습 능력을 더 잘 설명할 수 있을 것이며, 아동들을 어 
휘능력 만으로 평가하는 단편적인 기준을 넘어설 수 있을 것이라 는 연구 목표로, 본 연구에서는 학령전기 아동의 어휘능력과 선택 적 주의집중력을 평가하여 아동을 전통적으로 구분하는 방법의 언어장애 및 정상언어발달 아동이 아닌, 새로운 군집으로 구분이 가능한지를 분석 연구하였다. 또한 아동의 어휘 학습 능력은 12 회 기의 책 읽기 활동을 실시한 후 아동이 기존에 알지 못했던 수용 및 표현 어휘를 얼마나 학습하였는지 평가하였다. 함께 책 읽기 활동 은 아직 글을 읽을 수 없는 아동도 성인과 책 읽기 상황에 주의를 집중하여 새로운 어휘에 반복적으로 노출되게 함으로써 어휘를 습 득할 수 있게 하는 자연스러운 활동이다(Yim et al., 2018). 만약 선 택적 주의집중력이 아동의 어휘 학습을 예측할 수 있는 요인이라 면 선택적 주의집중력과 언어능력을 변인으로 나누어진 군집 간 어 휘 학습 능력에 유의한 차이가 있을 것이다. 이에 따른 연구문제는 다음과같다.

1. 아동의 선택적 주의집중력 및 언어능력에 따른 군집은 어떻게 분류되는가?

2. 새롭게 분류된 군집을 형성하는 아동들의 비율은 전통적으 로 구분되었던 언어발달장애와 정상 언어발달 아동 간 어떠한 양상으로 나타나는가?

3. 아동의 선택적 주의집중력에 따라 수용 및 표현 어휘 학습능 력에 유의한 차이가 있는가?

\section{연구방법}

\section{연구 대상}

경기 지역 어린이집의 만 4-6세 아동 33명(일반 아동 18 명, 단순 언어장애 아동 15 명)이 본 연구에 참여하였다.

본 연구의 일반 아동 집단은 (1) 부모 또는 어린이집 교사에 의해 인지, 언어, 신체능력이 정상이라고 보고되고, (2) 카우프만 아동용 지능검사(Korean Kaufman Assessment Battery for Children, K$\mathrm{ABC}$; Moon \& Byun, 2003)의 동작성 지능검사 결과 표준점수 85 점(-1 SD) 이상, (3) 수용·표현 어휘력검사(Receptive \& Expressive Vocabulary Test, REVT; Kim, Hong, Kim, Jang, \& Lee, 2009) 결과 수용 및 표현 어휘가 모두 정상 범주(-1 SD 이상)이며, (4) 취학 전 아동의 수용언어 및 표현언어 척도(Preschool Receptive-Expressive Language Scale, PRES; Kim, Sung, \& Lee, 2003) 결과 수용 및 표현언어가 모두 정상 범주(-1 SD 이상)이고, (5) 감각기관, 정서 및 행동발달에 신경학적 결함이 없는 아동을 대상으로 하였다.

단순언어장애 아동 집단은 (1) 부모 또는 어린이집 교사에 의해 인지, 신체능력이 정상이나 언어발달에 어려움이 보고되고, (2) K-
$\mathrm{ABC}$ 의 동작성 지능 표준점수가 85점(-1 SD) 이상, (3) REVT 결과 수용 및 표현 어휘 $10 \%$ ile 미만, (4) PRES 결과 수용 및 표현언어 $10 \% \mathrm{ile}$ 미만, (5) 감각기관, 정서 및 행동발달에 신경학적 결함이 없 는 아동을 대상으로 하였다.

일반 아동 집단의 평균 월령은 61.06 세 $(\mathrm{SD}=8.53)$, 단순언어장애 아동 집단의 평균 월령은 62.67 세 $(\mathrm{SD}=8.10)$ 로 두 집단 간 연령에 유의한 차이가 없었다 $\left(t_{(31)}=.553, p=.585\right)$. 그리고 일반 아동 집단 의 동작성 지능의 평균은 $105.72(\mathrm{SD}=11.39)$, 단순언어장애 아동 집단의 평균은 $108.40(\mathrm{SD}=12.40)$ 점으로 두 집단의 동작성 지능 또한 차이가 없었다 $\left(t_{(31)}=.646, p=.523\right)$. 어휘능력 및 언어능력의 차이를 살펴본 결과, 두 집단의 어휘능력 및 표현언어능력에 유의 한 차이가 있었다. 일반 아동 집단(M=56.28, $\mathrm{SD}=9.28)$ 은 단순언 어장애 아동 집단 $(\mathrm{M}=46.93, \mathrm{SD}=15.19)$ 보다 유의하게 수용 어휘 점수가 높았고, 마찬가지로 일반 아동 집단의 표현 어휘 점수 $(\mathrm{M}=$ $65.61, \mathrm{SD}=12.53)$ 도 단순언어장애 아동 집단 $(\mathrm{M}=47.00, \mathrm{SD}=14.67)$ 보다 유의하게 높았다. 일반 아동 집단의 수용언어 점수 $(\mathrm{M}=41.61$, $\mathrm{SD}=8.86)$ 와 단순언어장애 아동 집단의 수용언어 점수 $(\mathrm{M}=37.53$, $\mathrm{SD}=8.94)$ 에 유의한 차이가 없었으며, 표현언어 점수는 일반 아동 집단 $(\mathrm{M}=44.61, \mathrm{SD}=8.41)$ 이 단순언어장애 아동 집단 $(\mathrm{M}=37.13$, $\mathrm{SD}=9.61)$ 에 비해 유의하게 높은 것으로 나타났다 $\left(t_{(31)}=-2.383\right.$, $p=.023)$. 두 집단의 특성을 Table 1 에 제시하였다.

\section{연구 도구}

\section{선택적 주의집중력 과제(fruit-Stroop)}

본 연구는 선택적 주의집중력을 측정하는 도구로 스트룹 효과 (Stroop effect)를 전제로 하는 과일 스트룹 과제(Yim \& Han, 2019)

Table 1. Participants' characteristics

\begin{tabular}{lccc}
\hline Characteristic & TD (N=18) & SLI (N=15) & $t$ \\
\hline Age (mo) & $61.06(8.53)$ & $62.67(8.10)$ & .553 \\
Nonverbal IO ${ }^{\mathrm{a}}$ & $105.72(11.39)$ & $108.40(12.40)$ & .646 \\
REVT & & & \\
$\quad$ Receptive & $56.28(9.28)$ & $46.93(15.19)$ & $-2.172^{*}$ \\
$\quad$ Expressive & $65.61(12.53)$ & $47.00(14.67)$ & $-3.931^{*}$ \\
PRES & & & \\
$\quad$ Receptive & $41.61(8.86)$ & $37.53(8.94)$ & -1.311 \\
$\quad$ Expressive & $44.61(8.41)$ & $37.13(9.61)$ & $-2.383^{*}$ \\
\hline
\end{tabular}

Values are presented as mean (SD).

$\mathrm{SLI}=$ specific language impairment; $T \mathrm{D}=$ typically developing children; $\mathrm{REVT}=$ Receptive \& Expressive Vocabulary Test (Kim, Hong, Kim, Jang, \& Lee, 2009); PRES= Preschool Receptive-Expressive Language Scale (Kim, Sung, \& Lee, 2003).

a Korean Kaufman Assessment Battery for Children (K-ABC; Moon \& Byun, 2003). ${ }^{*} p<.05$. 
사용하였다. 연구자는 아동에게 '빨리 이름 말하기' 놀이를 하는 것으로 과제를 소개하였으며, 과제는 연습문항과 본문항으로 구성 되었다. 연습문항 단계는 하얀 배경의 화면에 다양한 색깔의 네모 5 개가 수평 방향으로 나란히 제시되면, 각 네모의 색깔을 좌에서 우 로 보면서 최대한 빠르고 정확하게 색깔 이름을 말하는 방식으로 진행되었다. 본문항은 (1) 네모 색깔 45초 안에 말하기, (2) 과일 색 깔 45초 안에 말하기, (3) 원래 과일 색깔 45초 안에 말하기의 세 단 계로 구성 및 실시되었다. 먼저 화면에 3 행 5 열로 15 개의 노랑, 빨강, 초록, 파란색 네모가 제시되면 아동은 각각의 네모가 무슨 색인지 제한시간(45초) 안에 가능한 한 빠르고 정확하게 말해야 한다. 이 어서 아동은 첫 번째 단계와 같이 $3 \times 5$ 배열로 제시되는 15 개의 과 일 그림을 보고 과일 각각의 색깔을 45 초의 제한시간 내에 최대한 빠르고 정확하게 말하도록 지시 받았다. 마지막 단계에서는 시각 자극 15 개가 3 행 5 열로 놓이나 원래 색깔과는 다른 색으로 칠해진 과일(e.g. 파란색 바나나)로서 제시된다. 아동은 각 과일의 통상적 인 색과 다르게 칠해진 과일 그림을 보고 해당 과일의 원래 색깔을 45 초 안에 가급적 빠르고 정확하게 말해야 한다. 소음이 없는 독립 된 장소에서 아동과 연구자가 일대일로 착석하여 검사를 실시하였 고, 아동이 연습문항을 통하여 과제를 충분히 이해한 것으로 판단 되면 본문항을 진행하였다. 각 단계에서 45 초가 되기 전에 아동이 15 개의 색깔 이름 대기를 모두 완료하면 첫 번째 그림으로 돌아가 서 45초가 될 때까지, 즉 연구자가 '그만'이라고 말하기 전까지 계속 하여 색깔 이름을 말하는 방식으로 진행되었다. 종속변수는 제한 된 시간 내에 3 단계에서 아동이 응답한 수로, 이는 응답시간과 오 류율을 측정하는 것보다 아동에게 더 적합한 방법이다(Archibald \& Kerns, 1999).

\section{책 읽기 활동을 통한 어휘중재}

본 연구에서는 Han, Kang과 Yim (2019)에서 제시한 책 읽기를 활용한 어휘중재를 실시하였다. 본 연구에서 사용한 책은 이상한 엄마(Baek, 2016), 도깨비를 빨아버린 우리 엄마(Sato, 1991), 치과 의사 드소토 선생님(Steig, 1995), 악어오리 구지구지(Chen, 2003) 이다(어린이도서연구회, 2017). 목표 어휘는 각 책에서 6개씩 총 24 개 선정하였고(Justice, Meier, \& Walpole, 2005), 책 내용과 어휘에 대해 언어병리학 박사과정 연구원 2 인이 내용타당도를 검증하였 다. 아동 별로 기초선을 설립하고자 사전평가를 통해 목표 어휘 24 개에 대한 표현 및 수용 어휘 평가를 실시하였다. 목표 어휘에 대한 검사는 REVT 검사 방식을 참고하여 실시하였다. 목표 어휘에 대한 표현 어휘 검사는 해당 그림을 보여주고 아동에게 이름을 말하도 록 하였으며, 수용 어휘 검사는 연구자가 목표 어휘를 말한 후 아동
이 네 개의 보기 중 하나의 그림을 고르도록 하였다. 평가에 필요한 그림자료는 노트북의 화면을 통해 제시하였다. 중재 충실도를 위해 책 읽기 중재 내용은 스크립트로 작성하여 아동에게 동일하게 제 시할 수 있도록 하였으며, 모든 중재자는 실험에 앞서 책 읽기 시의 말 속도, 억양 등을 일치시키기 위한 훈련을 사전 진행하여 제시되 는 자극 간 변이성을 줄일 수 있도록 하였다. 또한 책 읽기 도중 중재 자는 아동과 자연스러운 대화를 나누기도 하였으나, 대화 도중 목 표 어휘가 노출되지 않도록 하였다. 중재 충실도 검토를 위해 모든 과정은 아동 보호자의 동의 하에 동영상으로 녹화되었다. 아동들 은 독립된 공간에서 연구자와 일대일로 평가 및 중재에 참여하였 고, 평가와 중재는 모두 아동의 교육 기관에서 실시되었다.

아동은 한 회기마다 약 20분씩 주 2-3회 실시되는 책 읽기 활동 에 참여하였다. 책 읽기 활동은 매 회기마다 책 읽기 사전 활동, 책 읽기 본 활동, 책 읽기 사후 활동 총 3 단계로 구성되었다. 사전 활동 은 아동에게 목표 어휘를 나타내는 그림을 노트북 화면으로 제시 한 후 목표 어휘의 유의어와 정의를 설명해 주었고, 이 과정에서 목 표 어휘는 1 회 노출되었다. 화면을 통해 제시되는 그림은 어휘평가 에서 제시된 그림과 동일하였다. 예를 들어, 아동에게 목표 어휘인 ‘움켜잡다'에 대해 설명할 때는 그림을 보여주며 “'움켜잡다'는 '쥐 다' 같은 거고, 손가락을 접어서 힘 있게 꽉 잡는 것을 말해." 같이 유의어와 정의를 활용하여 설명해주었다. 책 읽기 본 활동에서 아 동은 연구자와 마주 앉아 연구자가 함께 목표 어휘가 포함된 책을 읽었다. 책 읽기 본 활동에서 목표 어휘는 1 회 노출되었다. 예를 들 어, "날카로운 발톱은 오리를 꽉 움켜잡을 수 있어." 같이 책의 본 문을 읽어 줌으로써 노출하였다. 책 읽기 사후 활동에서 연구자는 목표 어휘가 책에서 제시된 문맥과 다른 문맥 상황의 그림을 노트 북 화면을 통해 제시한 후, 그림의 문맥과 목표 어휘의 정의를 통해 아동에게 설명해주었으며, 책 읽기 사후 활동에서 목표 어휘는 1 회 노출되었다. 예를 들어, 아동에게 목표 어휘에 해당하는 그림을 사 전 활동의 그림과는 다른 문맥의 그림으로 제시하며 "엄마가 손가 락을 내밀었더니 아기가 꽉 움켜잡았어." 같이 그림의 문맥과 정의 를 활용하여 설명해주었다. 마지막 회기에는 사후평가가 포함되며, 사후평가는 사전평가와 동일한 내용으로 구성되었다. 사후평가의 표현 및 수용 어휘 평가는 REVT 평가 방식을 참고하여 실시하였으 며, 필요한 그림은 노트북 화면을 통해 제시되었다. 매 회기는 약 20 분으로, 신뢰도 검토를 위하여 모든 과정을 동영상으로 녹화하였 다. 마지막 회기에는 사후평가를 실시하여 목표 어휘 24 개에 대한 수용 및 표현 어휘 학습량을 평가하였다. 매 중재 회기마다 2 권의 책을 사용하였고, 전체적으로 4 권의 책을 2 권씩 짝지어 각 6 번씩 반복하여 목표 어휘는 각각 총 12 회 노출되었다. 


\section{연구 절차}

모든 대상자는 독립된 공간에서 연구자와 일대일로 본 연구에 참여하였으며, 선별검사 후 선택적 주의집중력 과제 및 책 읽기 중 재를 실시하였다. 각 아동 당 선별검사 및 본 과제까지 약 40 분 정도 의 시간이 소요되었다. 이후 중재에 사용될 목표 어휘의 기초선을 수립하고자 아동을 1 회기의 사전 평가에 참여시켜 표현 및 수용 어 휘 검사를 실시하였다. 그리고 아동은 어휘중재 프로그램에 주 2-3 회씩 총 4-5주 동안 참여하였다.

\section{자료 분석}

군집의 수를 결정하기 위해 선택적 주의집중력, 수용 어휘, 수용 언어 점수를 잠재변인으로 하는 2 단계 군집분석을 실시하였다. 군 집분석에는 표준화 점수( $\mathrm{Z} \mathrm{score)}$ 를 사용하였다. 2 단계 군집분석 후 분류된 군집 간 연령과 동작성 지능을 비교하기 위해 독립표본 $t$-test를 실시하였다. 그리고 군집 간 수용 및 표현 어휘 학습량을 비 교하기 위해 연령과 동작성 지능을 공변량으로 한 one-way AN$\mathrm{COVA}$ 를 실시하였다. 그리고 일반집단 및 단순언어장애 집단 간 수용 및 표현 어휘 학습량을 비교하기 위하여 독립표본 t-test를 실 시하였다.

\section{연구결과}

\section{아동의 선택적 주의집중력 특성에 대한 군집분석 결과}

아동의 선택적 주의집중력 특성에 따라 어떠한 군집이 형성되는
지 살펴보기 위해 선택적 주의집중력, 수용언어능력, 수용 어휘력 을 잠재변인으로 하는 2 단계 군집분석을 실시하였다. 1단계에서는 계층적 군집분석을 실시하였다. 그 결과, 군집 구분 변인으로 하는 선택적 주의집중력 $\left(F_{(1,31)}=14.986, p=.001\right)$, 수용언어 $\left(F_{(1,31)}=23.263\right.$, $p=.000)$, 수용 어휘 $\left(F_{(1,31)}=30.813, p=.000\right)$ 는 모두 군집분석에 유 의한 잠재변인으로 나타났다. 최종 군집 수는 2 개가 적당한 것으로 판단되어 2 단계에서 $\mathrm{K}$-평균 군집분석을 실시한 결과 군집 1 은 선택 적 주의집중력, 수용언어능력, 수용 어휘력이 평균 이하인 집단, 군 집 2는 평균 이상인 집단으로 분류되었다(Figure 1). 총 대상자 33명 중 14 명은 군집 1,19 명은 군집 2 로 분류되었다.

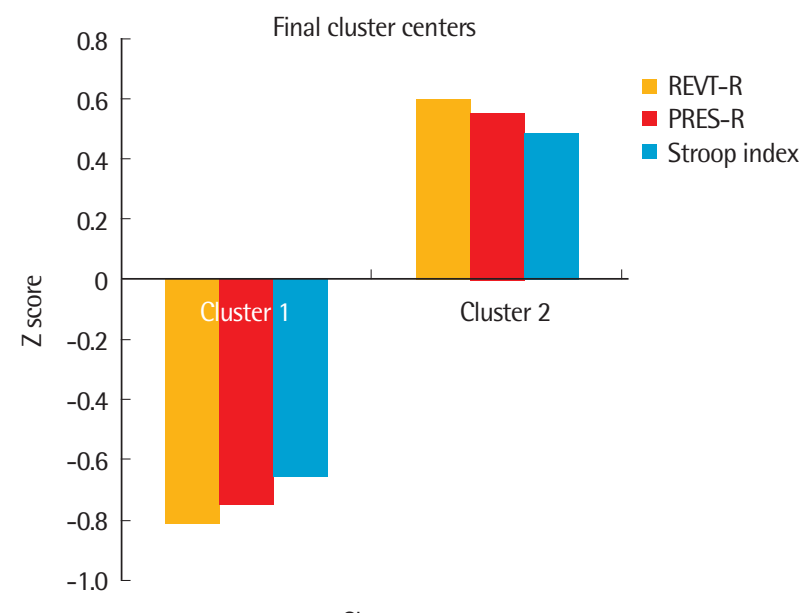

Cluster

Figure 1. K-mean cluster analysis.
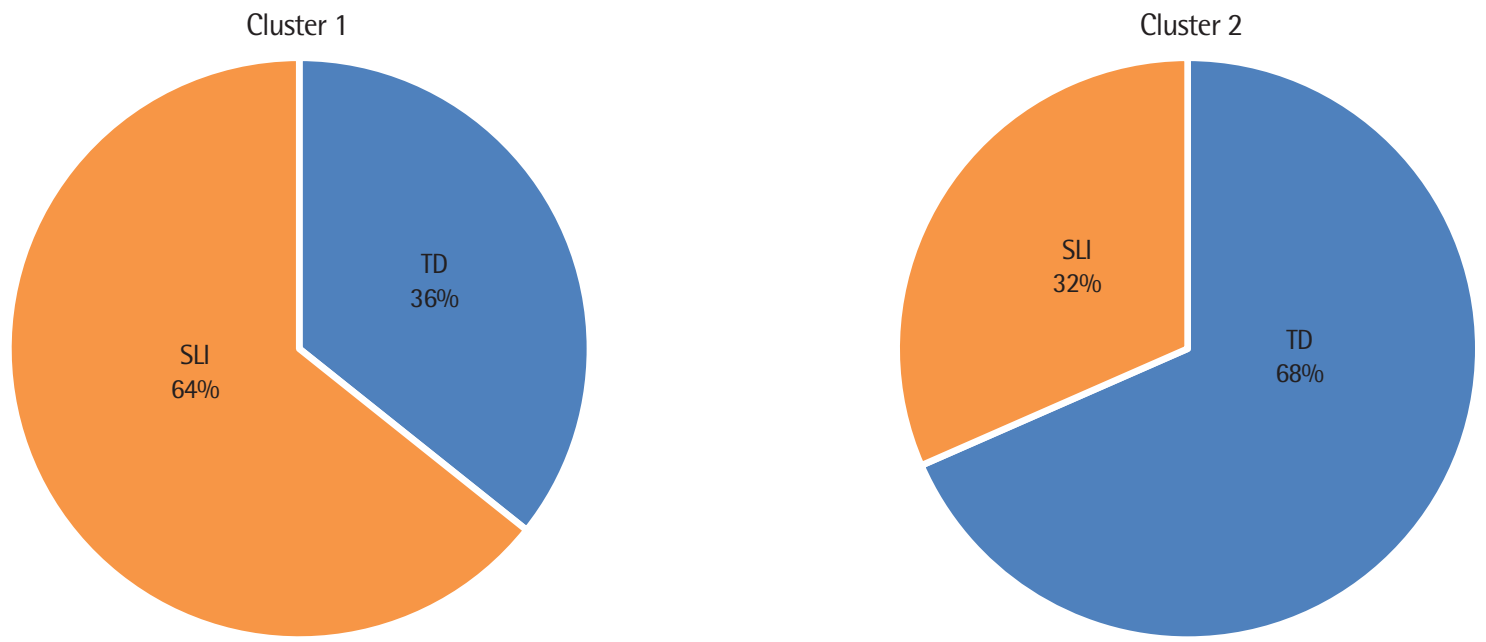

Figure 2. TD and SLI ratio in each cluster. The blue part represents typically developing children, and the orange part represent children with SLI.

$\mathrm{SLI}=$ specific language impairment; TD=typically developing children; REVT-R=Receptive vocabulary scores of Receptive and Expressive Vocabulary Test (REVT); PRES-R=Receptive language scores of Preschool Receptive-Expressive Language Scale (PRES). 


\section{군집 내 일반 아동 및 단순언어장애 아동 비율}

선택적 주의집중력을 집단 구분 변인으로 추가하여 군집분석을 실시한 뒤 각 군집 내 일반 아동 및 단순언어장애 아동의 비율을 분 석하였다. 수용 어휘, 수용언어, 선택적 주의집중력의 표준화점수 가 평균 이하였던 군집 1 에는 총 14 명 중 일반 아동이 5 명, 단순언어 장애 아동이 9 명으로 각각 $36 \%, 64 \%$ 의 비율로 구성되었다. 세 변인 의 표준화점수가 평균 이상이었던 군집 2 의 경우 총 19 명 중 일반 아동이 13 명, 단순언어장애 아동이 6 명으로 각각 $68 \%, 32 \%$ 의 비율 로 구성되었다(Figure 2).

두 군집 내 일반 아동 및 단순언어장애 아동의 연령, 동작성 지 능, 수용 및 표현 어휘, 수용 및 표현 언어 점수 기술통계는 Table 2
에 제시하였다. 그리고 독립표본 $t$-검정을 실시하여 분류된 군집 간 연령, 동작성 지능, 어휘, 언어점수 및 선택적 주의집중력 지수를 비 교하였다. 그 결과, 모든 변수에서 군집 2 의 평균이 군집 1 보다 높았 고 두 군집이 이질적인 집단임을 확인하였다. 특히, 군집 1 의 평균 월 령 $(\mathrm{M}=56.21, \mathrm{SD}=5.60)$ 이 군집 2 의 평균월령 $(\mathrm{M}=65.89, \mathrm{SD}=7.50)$ 보다 유의하게 높았고 $\left(t_{(31)}=-4.058, p=.000\right)$, 동작성 지능도 군집 1 $(\mathrm{M}=102.21, \mathrm{SD}=8.78)$ 이 군집 $2(\mathrm{M}=110.42, \mathrm{SD}=12.63)$ 보다 유의 하게 높았다 $\left(t_{(31)}=-2.083, p=.046\right)$.

\section{군집 간 어휘 학습능력 비교}

군집 간 연령과 동작성 지능에 유의한 차이가 있었기 때문에 이

Table 2. TD and SLI characteristics in each cluster.

\begin{tabular}{|c|c|c|c|c|c|c|c|}
\hline \multirow{2}{*}{ Characteristic } & \multicolumn{3}{|c|}{ Cluster $1(\mathrm{~N}=14)$} & \multicolumn{3}{|c|}{ Cluster 2 (N=19) } & \multirow{2}{*}{$t$} \\
\hline & $\mathrm{TD}(\mathrm{N}=5)$ & SLI (N=9) & Total & $\mathrm{TD}(\mathrm{N}=13)$ & $S L I(N=6)$ & Total & \\
\hline Age (mo) & $53.00(4.63)$ & $58.00(5.50)$ & $56.21(5.60)$ & $64.15(7.65)$ & 69.67 (6.08) & $65.89(7.50)$ & $-4.058^{* *}$ \\
\hline Nonverbal IO ${ }^{\mathrm{a}}$ & 99.80 (8.16) & $103.56(9.28)$ & $102.21(8.78)$ & 108.00 (11.89) & 115.67 (13.67) & 110.42 (12.63) & $-2.083^{*}$ \\
\hline \multicolumn{8}{|l|}{ REVT } \\
\hline Receptive & $46.80(6.76)$ & 38.56 (12.70) & $41.50(11.41)$ & $59.92(7.42)$ & $59.50(8.45)$ & $9.79(7.52)$ & $-5.551^{* *}$ \\
\hline Expressive & $53.80(9.68)$ & 42.56 (11.04) & $46.57(11.62)$ & $70.15(10.52)$ & 53.67 (17.85) & 64.95 (14.98) & $-2.488^{*}$ \\
\hline \multicolumn{8}{|l|}{ PRESS } \\
\hline Receptive & 33.40 (5.32) & 32.78 (4.68) & 33.00 (4.72) & 44.77 (7.92) & 44.67 (9.33) & 44.74 (8.13) & $-5.211^{* *}$ \\
\hline Expressive & 39.40 (11.78) & $35.22(10.17)$ & 36.71 (10.52) & 46.62 (6.19) & 40.00 (8.76) & 44.53 (7.54) & $-2.488^{* *}$ \\
\hline Selective attention & $9.20(4.55)$ & $10.89(9.18)$ & $10.29(7.68)$ & 19.69 (6.08) & $20.00(7.66)$ & $19.79(6.40)$ & $-3.871^{* *}$ \\
\hline
\end{tabular}

Values are presented as mean (SD).

SLI= specific language impairment; TD= typically developing children; REVT= Receptive \& Expressive Vocabulary Test (Kim, Hong, Kim, Jang, \& Lee, 2009); PRES= Preschool Receptive-Expressive Language Scale (Kim, Sung, \& Lee, 2003).

aKorean Kaufman Assessment Battery for Children (K-ABC; Moon \& Byun, 2003).

${ }^{*} p<.05,{ }^{* *} p<.01$.
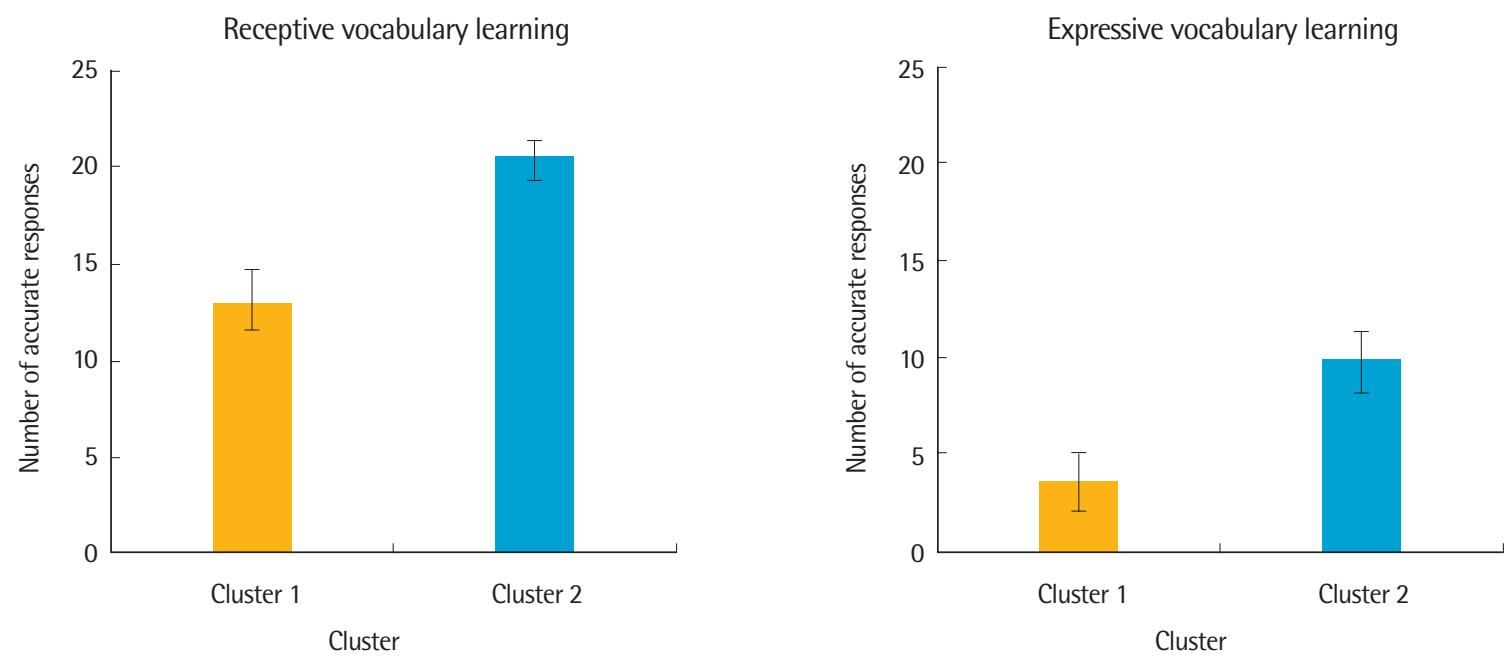

Figure 3. Comparisons of post receptive and expressive vocabulary scores between cluster 1 and 2 . ${ }^{*} p<.05$. 
Table 3. Comparisons of selective attention and post receptive and expressive vocabulary scores between TD and SLI.

\begin{tabular}{lrrr}
\hline Variables & TD $(n=18)$ & SLI $(n=15)$ & $t$ \\
\hline Selective attention & $16.78(7.37)$ & $14.53(9.51)$ & -.763 \\
Post receptive vocabulary scores & $18.77(5.68)$ & $15.66(6.35)$ & -1.484 \\
Post expressive vocabulary scores & $8.77(7.18)$ & $5.06(6.56)$ & -1.536 \\
\hline
\end{tabular}

Values are presented as mean (SD)

$S L I=$ specific language impairment; $T D=$ typically developing children .

를 공변량으로 하여 두 군집의 어휘 학습능력을 비교하였다. 그 결 과, 수용 어휘 학습량의 경우 군집 1 의 평균은 $12.92(\mathrm{SD}=6.45)$ 로 군집 2의 학습량 평균 $20.63(\mathrm{SD}=3.11)$ 보다 유의하게 낮았다 $\left(F_{(3,29)}\right.$ $=9.202, p=.005$, Partial $\left.\eta^{2}=.241\right)$. 표현 어휘 학습량의 경우 군집 1 은 평균 $3.50(\mathrm{SD}=5.73)$, 군집 2 는 평균 $9.73(\mathrm{SD}=6.87)$ 점으로 두 군 집 간 차이가 유의하지 않았다 $\left(F_{(3,29)}=1.705, p=.202\right.$, Partial $\eta^{2}=$ .056). 군집 1 과 2 의 수행은 Figure 3 에 제시하였다.

선택적 주의집중력을 추가한 잠재집단의 어휘 학습능력과, 전통 적인 집단(일반 아동 vs. 단순언어장애 아동) 간 어휘 학습능력 차 이를 비교하기 위하여 추가 분석을 실시하였다. 두 전통적인 집단 간 선택적 주의집중력, 어휘 학습능력에 대한 기술통계는 Table 3에 제시하였다. 그 결과, 선택적 주의집중력에서 일반 아동 집단 $(\mathrm{M}=$ $16.78, \mathrm{SD}=7.37)$ 과 단순언어장애 아동 집단 $(\mathrm{M}=14.53, \mathrm{SD}=9.51)$ 간 수행이 유의하지 않았다 $\left(t_{(31)}=-.763, p=.451\right)$. 수용 및 표현 어휘 학습량도 일반 아동 집단과 단순언어장애 아동 집단 간 유의한 차 이가 없었다 (수용: $t_{(31)}=-1.484, p=.148$; 표현: $t_{(31)}=-1.536, p=.135$ ).

\section{논의 및 결론}

어휘는 언어와 인지능력의 발달에 관여하는 기초적이고 필수적 인 요소이며, 어휘 능력이 정교하게 확장될수록 환경에서 접하는 수많은 언어적 정보를 보다 더 풍부하게 이해하고 산출할 수 있게 된다. 특히 아동의 수용 어휘 능력은 의사소통에 필수적이고 이후 의 읽기능력에도 일관되게 이어지는데(Scarborough, 2001), 이에 비추어 볼 때 어휘 학습능력은 읽기 및 문해능력 발달 측면에 중요 한 요소이다. 이러한 이유로 어휘 학습은 단순언어장애 아동에게 기초적이면서도 중대한 과제일 수 있다. 본 연구에서는 아동의 어 휘 학습 능력에 언어능력 외 다른 잠재 변인이 영향을 미칠 수 있다 고 가정하였고, 그 요인으로 선택적 주의집중력에 주목하였다. 이러 한 선택적 주의집중력은 작업기억과도 연관이 있고, 학습, 문제해 결, 작업기억의 효율적 기능 등에 핵심적인 역할을 수행한다(Posner \& Rothbart, 2000). 선택적 주의집중력은 어휘를 학습할 때 특
정 언어정보를 선별적으로 받아들이는 데 관여하기 때문에 어휘 학습에 중요한 요소라 볼 수 있으며(Campbell \& McNeil, 1985), 이 러한 이유로 어휘 학습의 개인차를 야기하는 요인으로 지목되기도 하였다. 만약 선택적 주의집중력이 아동의 어휘 학습능력을 예측 할 수 있는 요인이라면, 이를 단순언어장애 아동의 평가 및 중재에 활용할 수 있을 것이다. 기존 연구에서는 주로 언어 점수로 집단을 나누어 두 집단의 어휘 학습능력에 어떠한 차이가 있는지 알아보 았으나, 본 연구에서는 언어능력과 선택적 주의집중력을 변인으로 군집분석을 실시한 후, 두 군집 간 어휘 학습능력에 어떠한 차이가 있는지 알아보았다.

이를 위해 본 연구에서는 학령전기 단순언어장애 아동 15 명과 일반 아동 18 명을 대상으로 언어, 인지 표준화 과제 및 선택적 주의 집중력 과제를 실시한 후, 모든 대상자에게 연구자와 일대일의 방 식으로 주 2회, 총 4-5주 동안 목표 어휘를 12회 노출하는 방식으로 책 읽기 활동을 실시하였다. 또한, 대상자가 중재 후 목표 어휘를 얼 마나 학습했는지 알아보기 위하여 중재 전후로 목표 어휘에 대한 수용·표현 검사를 실시하였다. 이에 따른 연구 결과는 다음과 같다.

첫째, 아동의 선택적 주의집중력 점수를 군집분류 변인으로 포 함시켰을 때, 군집 분류 변인인 선택적 주의집중력은 군집분석에 유의한 변인으로 나타났으며 전체 아동은 두 군집으로 분류되었 다. 군집 1 은 14 명(일반 아동 5 명, 단순언어장애 아동 9 명)으로 선택 적 주의집중력, 수용언어능력, 수용 어휘력이 낮은 집단, 군집 2는 19 명(일반 아동 13명, 단순언어장애 아동 6 명)으로 선택적 주의집 중력, 수용언어능력, 수용 어휘력이 높은 집단으로 분류되었다.

일반 아동의 경우 18 명 중 5 명은 군집 1,13 명은 군집 2 로 분류되 었고, 15 명의 단순언어장애 아동은 9명, 6 씩 군집 1 과 2에 재 분류 되었다. 구체적인 비율을 살펴보면, 군집 1 은 일반 아동 $36 \%$, 단순 언어장애 아동 $64 \%$, 군집 2 는 일반 아동 $68 \%$, 단순언어장애 아동 $32 \%$ 로 구성되었다. 특히 단순언어장애 아동이 두 군집에 고르게 분포되었다는 점은 단순언어장애 아동 집단 중에서도 일반 아동과 유사한 선택적 주의집중력을 보이는 아동이 있다는 것을 의미하 며, 이러한 결과는 단순언어장애 아동의 어휘 학습 개인차를 설명 할 수 있는 근거가 된다(Roello et al., 2015). 선택적 주의집중력은 필요 없는 정보는 억제하고 필요한 정보는 선택하여 처리하는 능력 이므로 이러한 능력이 보존된 아동은 그렇지 않은 아동보다 학습 능력이 좋을 것이다(Wilson \& Kipp, 1998). 이러한 양상은 전통적 구분에 의하여 일반 아동과 단순언어장애 아동을 분류하고 두 집 단의 언어능력과 언어기저능력을 비교한 연구들과 달리, 단순언어 장애 아동의 선택적 주의집중력이 언어능력과 상호작용할 수 있다 는 점과 단순언어장애 아동의 발전 가능성을 시사한다. 
둘째, 책 읽기 중재 이후의 수용-표현 어휘 습득에 각 군집 간 어 떠한 차이점이 있었는지 알아본 결과, 군집 1 이 군집 2에 비해 수용 어휘 학습량이 유의미하게 낮았다. 그러나 표현 어휘의 경우 두 군 집간 학습량에 유의미한 차이가 없었다. 각 어휘가 12 회씩 노출되 는 동안 수용 어휘는 목표한 24 개 중 20개 이상 습득된 반면, 표현 어휘는 10 개 미만으로 습득되어 수용 및 표현 어휘 습득 속도에 차 이가 있는 것으로 나타났다. 이는 새롭게 형성된 어휘 개념이 구어 로 산출되는 과정은 수용 어휘보다 더 복잡한 처리과정을 포함하 는 데 기인한 결과로 보인다. 이와 같이 잠재변인을 포함하여 분류 한 두 군집 간 어휘 학습량에 차이가 나는 것은 선택적 주의집중력 이 어휘 학습에 영향을 미치는 요인이라는 본 연구의 가설을 검증 하였다고 할 수 있다. 기존의 선행연구에서 선택적 주의집중력이 아동의 어휘 학습에 중요한 요인이 될 수 있다는 연구결과는 많이 있었으나, 실제로 선택적 주의집중력을 변인으로 포함하여 집단 구 분 기준을 기존 연구와 달리 설정한 후 두 집단의 어휘 학습능력 차 이를 살펴본 연구는 없었다. 또한 이렇게 구분한 두 군집 간 실제 어 휘 학습능력에 유의미한 차이가 있는 것은 임상현장에 시사하는 바가 크다. 다시 말해, 아동의 언어발달의 근간이 될 수 있는 어휘 학습능력에 선택적 주의집중력이 영향을 미칠 수 있으므로 아동 의 평가 시 비공식적인 검사도구로 활용하거나 중재에 활용하여 그 효과와 지속성을 높일 수 있다.

또한 추가 분석을 실시하여 선택적 주의집중력 없이 언어점수만 으로 구분한 일반 아동 집단과 단순언어장애 아동 집단 간 선택적 주의집중력, 어휘 학습능력에 차이가 있는지 알아본 결과, 선택적 주의집중력에서 집단 간 수행에 유의한 차이가 없었으며, 수용 및 표현 어휘 학습량도 일반 아동 집단과 단순언어장애 아동 집단 간 유의한 차이가 없었다. 이와 같은 결과는 아동의 언어점수만으로 집단을 구분했을 때보다 선택적 주의집중력을 포함하여 집단을 구 분하였을 때 두 집단 간 어휘 학습능력의 차이를 더 잘 설명할 수 있고, 어휘 학습능력에 선택적 주의집중력이 중요하다는 본 연구의 가설을 일관되게 뒷받침한다. 그리고 이러한 결과는 언어점수만 고 려하여 집단을 구분하던 전통적인 집단 구분 방식에 의문점을 제 기할 수 있다. 최근 지속적으로 주장되어 오는 정보처리 이론에 입 각하여 아동의 언어발달을 언어능력(기존에 학습하여 장기기억에 저장된 내용)만으로 평가하는 것이 아니라, 언어발달에 중요한 근 본적인 요인에 초점을 맞추어 전반적이면서도 큰 그림을 그릴 수 있 는 방안을 제시하고자 하였다.

이에 따른 본 연구의 의의 및 제안점은 다음과 같다.

본 연구에서는 수용어휘 과제에서 두 군집 간 유의한 차이를 보 고하였다. 그러나 수용어휘 과제가 선택적 집중력과 직접적으로 관
련되어 있는 과제라는 점을 고려할 때 이러한 결과는 과제 특성이 반영된 결과로 자칫 해석될 수 있다. 따라서 후속 연구에서는 과제 특성을 배제할 수 있는 언어과제를 통해 선택적 집중력으로 나눈 군집 간 특성을 살펴볼 필요가 있다. 그리고 더 많은 대상자에게 군 집분석을 실시했을 때도 선택적 주의집중력이 유의한 군집 분석 요 인으로 나타난다면, 더 설득력 있는 결과를 도출할 수 있을 것으로 기대한다.

다음으로, 아동의 어휘 학습능력을 평가한 방법에 있어 본 연구 는 책 읽기 활동을 선택하여 아동의 실생활에서의 어휘 학습과 유 사한 방식으로 접근했다는 점에서 의미가 있다. 기존 연구에서는 아동이 어휘를 학습하는 능력과 선택적 주의집중력의 관계를 주로 빠른우연학습(Quick Incidental Learning, QUIL)을 통해 알아보 았는데(Yang et al., 2015; Yang \& Yim, 2018; Yoon \& Yim, 2019), 빠 른우연학습은 아동이 새롭게 접하는 어휘를 참조물과 빠르게 연 결하여 순간적으로 학습하는 능력인 빠른 연결(fast mapping)을 평가할 수 있는 과제이다(Yang, Yim, Kim, \& Han, 2013). 한편 본 연구는 아동이 4-5주의 기간 동안 연구자와 주 2 회 일대일로 책을 읽으면서 지속적이고 반복적인 어휘 학습이 이루어지도록 하였다. 이처럼 지속적인 과정을 통한 어휘 학습은 아동이 일상생활에서 부모와 함께 책을 읽거나 스스로 책을 읽는 과정, 혹은 치료실에서 치료사와 반복적으로 어휘를 학습하는 과정과 유사하다. 이러한 점을 고려할 때, 반복적인 노출을 통해 어휘를 학습하는 능력에 선 택적 주의집중력이 중요하다는 점을 밝힌 본 연구는 임상적으로 큰 의미가 있다. 두 언어를 동시에 사용하는 이중언어 아동을 대상 으로 한 연구에서도 아동의 어휘 학습에 선택적 주의집중력이 중 요할 뿐만 아니라 단순언어장애 아동의 선별 시, 특히 어린 연령의 아동에 대하여 선택적 주의집중력이 유용하다는 것을 밝힌 바 있 다(Laloi, de Jong, \& Baker, 2017). 다시 말해 본 연구의 결과를 활용 하여 임상에서 아동의 초기 평가 시 표준화된 검사뿐 아니라 아동 의 선택적 주의집중력을 측정함으로써 아동이 보유한 선택적 주의 집중력을 함께 고려하여 치료의 목표를 설정하고 방향을 계획할 수 있다. 여기에는 주의집중력 분산을 방지할 수 있는 환경 조성, 간 섭 효과를 배제할 수 있는 활동 구성 등이 있을 것이다. 또한, 선택 적 주의집중력에 따라 목표를 수립하는 것에 그치지 않고, 선택적 주의집중력 또한 지속적인 발달 가능성을 가진 능력임을 염두에 두고 관련 활동을 구성해 나가는 방안도 함께 고려되어야 한다.

\section{REFERENCES}

Archibald, S., \& Kerns, K. (1999). Identification and description of new tests 
of executive functioning in children. Child Neuropsychology, 5(2), 115-129.

Bishop, D. V. M., \& Norbury, C. F. (2005). Executive functions in children with communication impairments, in relation to autistic symptomatology: II. response inhibition. Autism, 9(1), 29-43.

Campbell, T. F., \& McNeil, M. R. (1985). Effects of presentation rate and divided attention on auditory comprehension in children with an acquired language disorder. Journal of Speech, Language, and Hearing Research, 28(4), 513-520.

Chun, S., \& Yim, D. (2017). A comparative study of chunking mechanism in children with and without language delay. Communication Sciences \& Disorders, 22(2), 233-244.

Ebert, K. D., \& Kohnert, K. (2011). Sustained attention in children with primary language impairment: a meta-analysis. Journal of Speech, Language, and Hearing Research, 54(5), 1372-1384.

Garon, N., Bryson, S. E., \& Smith, I. M. (2008). Executive function in preschoolers: a review using an integrative framework. Psychological Bulletin, 134(1), $31-60$.

Gathercole, S. E., Willis, C. S., Emslie, H., \& Baddeley, A. D. (1992). Phonological memory and vocabulary development during the early school years: a longitudinal study. Developmental Psychology, 28(5), 887-898.

Justice, L. M., Meier, J., \& Walpole, W. (2005). Learning new words from storybooks: findings from an intervention with at-risk kindergarteners. Language, Speech, and Hearing Services in Schools, 36(1), 17-32.

Han, J., Kang, D., \& Yim, D. (2019). Step-by-step word learning: finding the optimal amount of word exposure. Proceedings of the 2019 conference of the KASA \& KSHA, 179-180.

Kail, R. (1994). A method for studying the generalized slowing hypothesis in children with specific language impairment. Journal of Speech, Language, and Hearing Research, 37(2), 418-421.

Kail, R., \& Salthouse, T. A. (1994). Processing speed as a mental capacity. Acta Psychologica, 86(2-3), 199-225.

Kapa, L., Plante, E., \& Doubleday, K. (2017). Applying an integrative framework of executive function to preschoolers with specific language impairment. Journal of Speech, Language, and Hearing Research, 60(8), 2170-2184.

Kim, Y. T., Hong, G. H., Kim, K. H., Jang, H. S., \& Lee, J. Y. (2009). Receptive \& Expressive Vocabulary Test (REVT). Seoul: Seoul Community Rehabilitation Center.

Kim, Y. T., Sung, T. J., \& Lee, Y. K. (2011). Preschool Receptive-Expressive Language Scale (PRES). Seoul: Seoul Community Rehabilitation Center.

Laloi, A., de Jong, J., \& Baker, A. (2017). Can executive functioning contrib- ute to the diagnosis of SLI in bilingual children? Linguistic Approaches to Bilingualism, 7(3), 431-459.

Leonard, L. B. (1986). Conversational replies of children with specific language impairment. Journal of Speech, Language, and Hearing Research, 29(1), 114119.

Marcovitch, S., \& Zelazo, P. D. (2009). A hierarchical competing systems model of the emergence and early development of executive function. Developmental science, 12(1), 1-18.

Miller, C. A., Kail, R., Leonard, L. B., \& Tomblin, J. B. (2001). Speed of processing in children with specific language impairment. Journal of Speech, Language, and Hearing Research, 44(2), 416-433.

Montgomery, J. W. (1993). Haptic recognition of children with specific language impairment: effects of response modality. Journal of Speech, Language, and Hearing Research, 36(1), 98-104.

Montgomery, J. W., Evans, J. L., \& Gillam, R. B. (2009). Relation of auditory attention and complex sentence comprehension in children with specific language impairment: a preliminary study. Applied Psycholinguistics, 30(1), 123-151.

Moon, S. B., \& Byun, C. J. (2003). Korean Kaufman Assessment Battery for Children (K-ABC). Seoul: Hakjisa.

Posner, M., \& Rothbart, M. (2000). Developing mechanisms of self-regulation. Development and Psychopathology, 12(3), 427-441.

Roebuck, H., Sindberg, H., \& Ellis Weismer, S. (2018). The role of language in nonlinguistic stimuli: comparing inhibition in children with language impairment. Journal of Speech, Language, and Hearing Research, 61(5), 1216-1225.

Roello, M., Ferretti, M. L., Colonnello, V., \& Levi, G. (2015). When words lead to solutions: executive function deficits in preschool children with specific language impairment. Research in Developmental Disabilities, 37, 216-222.

Scarborough, H. S. (2001). Connecting early language and literacy to later reading (dis)abilities: evidence, theory and practice. In S. Neuman \& D. Dickinson (Eds.), Handbook for research in early literacy (pp. 97-110). New York: Guilford Press.

Spaulding, T. J. (2010). Investigating mechanisms of suppression in preschool children with specific language impairment. Journal of Speech, Language, and Hearing Research, 53(3), 725-738.

Wilson, S. P., \& Kipp, K. (1998). The development of efficient inhibition: evidence from directed-forgetting tasks. Developmental Review, 18(1), 86-123.

Yang, Y., Yim, D., Kim, S., \& Han, J. (2013). The relationship among receptive vocabulary, non-word repetition, and quick incidental learning in pre- 
schoolers with and without delay in vocabulary development. Communication Sciences \& Disorders, 18(4), 379-391.

Yang, Y., Yim, D., \& Bae, K. (2015). Predictors of word learning in children with specific language impairment. Communication Sciences \& Disorders, 20(1), 1-12.

Yang, Y., \& Yim, D. (2018). The role of executive function for vocabulary acquisition and word learning in preschool-age children with and without vocabulary delay. Communication Sciences \& Disorders, 23(1), 43-59.

Yim, D., \& Han, J. (2019). Phonological loops, visuospatial sketchpad, episodic buffers, and inhibition in children with a language delay. Korean Journal of Special Education, 54(2), 183-204.

Yim, D., Kim, S., Han, J., Park, W., Song, E., ... Yoon. S. (2018). Intervention and transfer effect of parent training on book reading: parental use of reading strategies, child utterances, and parent-child interaction skills. Korean Journal of Special Education, 53(2). 179-206.

Yoo, J., \& Yim, D. (2018). Relationship among executive functions, vocabulary and reading skills in school-aged children with and without poor vocabulary. Communication Sciences \& Disorders, 23(3), 570-583.

Yoon, S., \& Yim, D. (2019). Sustained attention of children with and without specific language impairment (SLI) and the relations with quick incidental learning using eye-tracker. Communication Sciences and Disorders, 24(4), 852-867.

Zelazo, P. D., \& Müller, U. (2010). Executive function in typical and atypical development. In U. Goswami (Ed.), The Wiley-Blackwell handbook of child cognitive development(2nd ed.)(pp.574-603). Oxford, UK: Wiley-Blackwell. 


\section{국문초록}

\section{선택적 주의집중 잠재집단에 따른 아동의 어휘 학습량 비교 연구 \\ 임동선 · 한지윤 · 송 은 · 이수경 · 한지아 \\ 이화여자대학교 언어병리학과}

배경 및 목적: 선택적 주의집중력은 학습에 영향을 미치는 중요한 능력이다. 따라서 선택적 주의집중력에 따라 학습 효과가 다르게 나 타날 수 있다. 본 연구는 군집분석을 통해 학령전기 단순언어장애 아동과 일반아동을 선택적 주의집중력에 따라 두 군집으로 분류하 였다. 그리고 책을 활용한 어휘 중재를 실시하여 두 집단의 어휘 학습량을 비교함으로써 궁극적으로 집단 구분 시 언어점수뿐만 아니 라 아동의 발달 가능성을 가늠할 수 있는 선택적 주의집중력을 집단 구분 시 포함해야한다는 점을 부각하고자 하였다. 방법: 만 4-6세 아동 33 명(일반 아동 18 명, 단순언어장애 아동 15 명)을 대상으로 선택적 주의집중력을 잠재변인으로 한 군집분석을 실시하여 전체 대 상자를 두 집단으로 나누었다. 분류된 두 집단에 책을 활용한 어휘 중재를 실시하고 목표 어휘에 대한 수용 및 표현 어휘 학습량을 측정 하여 집단 간 차이를 살펴보았다. 결과: 선택적 주의집중력은 군집분석에 유의한 변인으로 나타났으며, 선택적 주의집중력에 따라 분류 된 두 집단은 연령과 동작성 지능을 통제하였을 때 수용 어휘 학습량에 대하여 군집 간 유의한 차이를 보였다. 그러나 선택적 주의집중 력을 제외하고 일반 아동과 단순언어장애 아동 간 어휘 학습량을 비교하였을 때에는 두 집단간 차이가 없었다. 논의 및 결론: 선택적 주의집중력을 잠재변인으로 하여 군집을 나누었을 때 두 군집에 단순언어장애 아동과 일반 아동이 고르게 분포되었음에도 어휘 학습 량에 유의한 차이가 나타났다. 이는, 선택적 주의집중력이 어휘 학습의 개인차를 야기하는 중요한 요인이며 아동의 선택적 주의집중력 에 따라수용 어휘 학습 예후가 달라질 수 있다는 점을 시사한다.

핵심어: 어휘 학습, 잠재요인, 선택적 주의집중력, 군집분석, 개인차

본 연구는 2019년 대한민국 과학기술정보통신부와 한국연구재단의 지원을 받았음(No. NRF-2019R1A2C1007488).

\section{참고문헌}

김영태, 홍경훈, 김경희, 장혜성, 이주연(2009). 수용·표현 어휘력 검사(Receptive \& Expressive Vocabulary Test; REVT). 서울: 서울장애인종합복지관. 김영태, 성태제, 이윤경(2003). 취학전 아동의 수용언어 및 표현언어 발달척도(PRES). 서울: 서울장애인종합복지관.

문수백, 변창진(2003). K-ABC 교육·심리측정도구 (Korean-Kaufman Assessment Battery for Children; K-ABC). 서울: 학지사.

백희나(2016). 이상한 엄마. 서울: 책 읽는 곰.

사토 와키코(이영준 역). 도깨비를 빨아버린 우리 엄마. 서울: 한림출판사.

양윤희, 임동선, 김신영, 한지윤(2013). 학령 전 어휘발달지체 및 일반 아동의 비단어 따라 말하기, 빠른 우연학습(Quick Incidental Learning)과 수용

어휘와의 관계. 언어청각장애연구, $18(4), 379-391$.

양윤희, 임동선, 배경란(2015). 학령기 단순언어장애 아동의 어휘학습 예측요인: 의미점화 및 간섭 효과. 언어청각장애연구, 20(1), 1-12.

양윤희, 임동선(2018). 학령전기 어휘발달지연 및 또래 아동의 어휘습득을 위한 집행기능의 역할. 언어청각장애연구, 23(1), 43-59.

어린이도연구회. "2017 어린이도연구회가 뽑은 어린이·청소년 책”, 2019. 3. 1, http://www.childbook.org/new3/netc.html?html= netc_main7.html 유지원, 임동선(2018). 학령기 어휘취약아동 및 또래 아동의 집행기능과 어휘 및 읽기능력과의 관계. 언어청각장애연구, 23(3), 570-583.

윤소망, 임동선(2019). 단순언어장애 아동과 정상 발달 아동의 지속주의 능력과 시선추적연구를 통한 빠른우연학습의 관계. 언어청각장애연구,

24(4), 852-867.

임동선, 김신영, 한지윤, 박원정, 송은, 이상언, 윤소망(2018). 책일기 부모교육이 부모의 전략, 아동의 발화, 상호작용에 미치는 영향 및 전이 효과. 특수

교육학연구, 53(2), 179-206.

임동선, 한지윤(2019). 언어발달지체 아동의 음운루프, 시공간잡기장, 일화적 완충기, 억제기능과 문법 능력 간의 관계. 특수교육학연구, 54(2), 183-204. 한지윤, 강다은, 임동선 (2019). 어휘노출횟수에 따른 단계별 어휘 학습양상. 제 6회 한국언어청각임상학회·한국언어치료학회 공동학술대회, 179-180. 
윌리엄 스타이그(조은수 역). 치과의사드소토 선생님. 서울: 비룡소.

천즈위엔(박지민 역). (2003). 악어오리 구지구지. 서울: 예림당.

천소연, 임동선(2017). 단어목록 회상을 통한 언어발달지체 아동과 일반아동의 덩이짓기 능력 연구 언어청각장애연구, 22(2), 233-244.

\section{ORCID}

임동선(제1저자, 교신저자, 교수 http://orcid.org/0000-0001-8254-9504); 한지윤(공동저자, 박사과정 http://orcid.org/0000-0002-7570-6679); 송은(공동저자, 박사과정 http://orcid.org/0000-0003-4867-7857); 이수경(공동저자, 석사과정 http://orcid.org/0000-0001-9175-9810); 한지아(공동저자, 석사과정 http://orcid.org/0000-0002-2563-0944) 